\title{
Dampak Covid-19 Terhadap Implementasi Pendidikan Karakter
}

\author{
${ }^{1}$ Mohammad Rudiyanto, ${ }^{2}$ Ria Kasanova \\ ${ }^{1}$ Program Pendidikan Studi Bahasa Inggris, FKIP, ${ }^{2}$ Program Studi Pendidikan Bahasa Indonesia \\ Universitas Madura \\ email: ${ }^{1}$ mohammadrudiyanto5@gmail.com, ${ }^{2}$ kasanovaria@unira.ac.id
}

\begin{abstract}
Abstrak
Wabah virus korona baru bernama Covid-19 telah menewaskan banyak orang di hampir setiap negara di dunia. Peneliti meyakini virus tersebut berasal dari pasar tradisional di Wuhan, China. Pasar tersebut menjual berbagai hewan segar dan lembab seperti kelelawar dan ikan, yang akhirnya menginfeksi manusia dengan virus. Organisasi Kesehatan Dunia (WHO) telah mengonfirmasi bahwa virus Covid-19 menyebar melalui perilaku manusia ketika berbicara, bersin, dan batuk dari orang yang terinfeksi. Penelitian ini menggunakan metode kualitatif untuk menyelidiki hubungan umum pengaruh covid terhadap perilaku karakter. Studi ini menemukan bahwa terdapat pengaruh Covid-19 terhadap penggunaan pendidikan karakter. Kesimpulan ini dapat ditarik dari faktor-faktor yang mempengaruhi sebagian besar karakter yang ditemui selama wabah Covid-19, seperti naluri, kebiasaan, kemauan, dan kebijaksanaan.
\end{abstract}

Kata kunci: covid-19, pendidikan karakter

\section{Impact of Covid-19 on The Implementation of Character Education}

\begin{abstract}
The new corona virus outbreak named Covid-19 has killed many people in almost every country in the world. Researchers believe the virus originated in a traditional market in Wuhan, China. The market sells a variety of fresh and moist animals such as bats and fish, which eventually infect humans with the virus. The World Health Organization (WHO) has confirmed that the Covid-19 virus spreads through human behavior when speaking, sneezing and coughing from infected people. This study used a qualitative method to investigate the general relationship between the influence of covid and character behavior. This study found that there is an effect of Covid-19 on the use of character education. This conclusion can be drawn from the factors that influenced most of the characters encountered during the Covid-19 outbreak, such as instincts, habits, willpower, and wisdom.
\end{abstract}

Keywords: covid-19, character education

\section{PENDAHULUAN}

Menurut WorldoMeters, akan ada 95.187 Covid-19 baru pada Sabtu 16 Mei 2020 dari total 4.617.176 unit di seluruh dunia, dari 4.617.176 kasus, 307.988 meninggal dan 1.749.199 dirawat. Indonesia saat ini menempati urutan ke 34 dari 34 kasus COVID-19 dan terdapat 490 kasus baru. Sebanyak 16.496 orang. Bagaimanapun, Indonesia memiliki angka kematian Covid-19 tertinggi di Asia Tenggara dengan populasi 1.076. Dengan meningkatnya jumlah kematian, pemerintah telah menetapkan aturan dan pedoman untuk menangani kasus Covid 19. Kebutuhan mendesak untuk mengatur pencegahan Covid-19 diumumkan oleh pemerintah pusat dan perintah Kementerian Kesehatan. Hal ini disebabkan karena kedua isntansi ini adalah adalah pihak yang berwenang terhadap kasus covid-19 [1]

Perlakuan pemerintah termasuk mengurangi jumlah korban di Indonesia dengan adanya Covid-19 diperlakukan pembatasan sosial bersekala besar. Selain itu, Kementerian Kesehatan telah mengeluarkan peraturan tentang PSBB (pembatasan sosial bersekala besar) tersebut. Tujuan PSBB adalah membatasi aktivitas penduduk di wilayah tertentu yang diduga terkena penyakit untuk mencegah penyebaran penyakit yang terjadi dengan memakai masker, membatasi angkutan umum, menjaga jarak saat bekerja, menjaga jarak jalan, tinggal di rumah dan tidak bepergian [2]

Masalah yang muncul ketika wabah Covid-19 adalah ketidaktaatan warga terhadap PSBB yang laksanakan pemerintah (pembatasan sosial bersekala besar) dan orang tidak dapat menjaga diri mereka sendiri selama wabah Covid-19 ini terjadi. Salah satu alasan ketidaktaatan dan ketidakpedulian orang adalah bahwa kepentingan pribadi sehingga melanggar hukum. Mereka yang tidak mengikuti aturan pemerintah untuk menaati PSBB menunjukkan bahwa mereka tidak peduli pada lingkungan. 
Karakter, menurut Samani, adalah nilai perilaku manusia yang berkaitan dengan sikap yang berdasarkan pada Tuhan Yang Maha Esa, jiwa, persaudaraan manusia, keadaan, dan kepercayaan, norma agama, hukum, moral, budaya, adat istiadat, dan tercermin dalam emosi, cara berbicara dan tindakan [3].

Dalam menyikapi masalah Covid-19 ini, peraturan pemerintah harus dipatuhi. Pemerintah dan masyarakat bekerja sama untuk memberantas virus COVID-19 ini merupakan bentuk kerja sama dan dedikasi yang bisa digunakan untuk mengalahkan Covid-19. Jadi penting untuk mengikuti pemerintah untuk melawan Covid-19. Berdasarkan uraian di atas, penulis berkeinginan untuk melakukan penelitian yang berjudul Dampak Covid-19 terhadap pelaksanaan pendidikan karakter.

\section{METODE PENELITIAN}

Penelitian ini menggunakan pendekatan kualitatif untuk mencari literatur dari berbagai sumber termasuk media cetak,artikel, buku, dan majalah [4]. Pencarian jurnal dilakukan melalui Google Scholar. Berdasarkan hasil pencarian, dipilih data dari data yang memenuhi kriteria [5]. Analisis pencarian literatur meliputi pengumpulan data, pengelompokan data, penyajian data dan penarikan kesimpulan.

\section{HASIL DAN PEMBAHASAN}

\subsection{Covid-19}

Covid-19 adalah epidemi yang disebabkan oleh jenis virus corona baru. Ini adalah virus baru yang tidak diketahui sebelum menyebar ke Wuhan, Cina pada Desember 2019 (WHO, 2020). Virus corona merupakan kelompok virus yang menyebabkan berbagai macam penyakit, mulai dari flu biasa hingga penyakit yang lebih serius seperti MERS dan SARS [6].

Gejala Covid-19 yang paling umum adalah demam, rasa tidak nyaman, dan batuk kering bahkan beberapa orang mungkin mengalami nyeri, hidung tersumbat, pilek, sakit tenggorokan, atau diare. Gejala yang diperiksa biasanya ringan dan muncul secara bertahap. Beberapa orang yang terinfeksi tidak menunjukkan gejala dan tetap merasa sehat.

Kebanyakan pasien (sekitar 80\%) sembuh tanpa perawatan khusus namun satu dari enam orang dengan Covid-19 akan mengalami sakit parah jika memiliki masalah pernapasan seperti orang tua (lansia) dan mereka yang sudah memiliki gejala seperti tekanan darah tinggi, penyakit jantung dan diabetes lebih serius (WHO, https: //www.who.int/indonesia/news, 2020). Penularan dari manusia ke manusia telah dikonfirmasi yang disebabkan oleh batuk dan bersin [7]

Dari uraian atas kita dapat menyimpulkan bahwa Covid 19 adalah penyakit yang serius dan menular dan pada saat yang sama belum ada vaksinnya, sehingga perlu dilakukan pengawasan penyakit ini. Dengan demikian solusi terbaik adalah dengan mengimplementasikan aturan pemerintah sebagai implementasi pendidikan karakter.

\subsection{Pendidikan Karakter}

Kata character berasal dari bahasa Yunani charasa yang berarti patung (melukis, menggambar), seperti seseorang yang menggambar di atas kertas atau memotong batu atau logam. Karakter yang berasal dari konsep ini diartikan sebagai tanda atau ciri khusus, yang mengarah pada gagasan bahwa karakter adalah "model perilaku individu, keadaan moral individu" [8].

Russell Williams menggambarkan karakter tersebut sebagai "otot" yang kendur saat tidak berlatih, te namun bertenaga jika sering digunakan. Dengan demikian esensi karakter merupakan potensi manusia yang harus dikembangkan dan dimanfaatkan [9] .Dengan kata lain, karakter biasanya diartikan sebagai kemanusiaan. Hal ini dikarenakan banyaknya karakteristik yang bergantung pada unsur-unsur kehidupan[10]. Pembangunan karakter adalah pendidikan yang didasarkan pada nilai-nilai moral dasar yang berakar dalam masyarakat demokratis, terutama penghormatan, tanggung jawab, kepercayaan, keadilan, keadilan, toleransi, kebajikan dan sosial [1].

Pendidikan karakter adalah proses mempertahankan nilai-nilai sebagai ide dan proses untuk menumbuhkan dan mempraktikkan nilai-nilai tersebut sehingga seseorang memiliki kesempatan untuk menerapkan nilai-nilai tersebut [11].

Rikuna lebih jelas menyatakan bahwa gagasan pendidikan karakter adalah upaya sadar untuk membantu individu memahami, memelihara dan mempraktikkan nilai-nilai moral yang sebenarnya[6]. Tujuan pengembangan karakter adalah untuk mengembangkan nilai-nilai yang membentuk karakter masyarakat indonesia. Ini termasuk: (2) pondasi negara yang diidentifikasi oleh Pancasila. (3) Meningkatkan kepercayaan pada warga negara, kemampuan bangga akan bangsa dan negara, serta kemampuan mencintai kemanusiaan [9]. Selain itu, pendidikan karakter hendaknya membentuk karakter seseorang agar dapat berperilaku jujur, baik hati, bertanggung jawab, menghargai dan bertoleransi kepada orang lain, kesetaraan, kerja keras, dan suka menolong lainnya. Kebiasaan gaya hidup yang nyata dapat membantu untuk mencapai tujuan pendidikan karakter [12].

Dari penjelasan tersebut dapat disimpulkan bahwa pembentukan karakter, pembentukan kepribadianr, pembentukan moral dan pembinaan yang layak disajikan secara baik dan sistematis. Tujuannya untuk mengembangkan kemampuan individu atau siswa dalam mengenali dan mengimplementasikan aspek positif 
kehidupan sehari-hari seperti kejujuran, ketekunan, dan rasa hormat kepada orang lain, tanggung jawab, keadilan, dan teguh pendirian.

\subsection{Faktor-faktor yang Mempengaruhi Karakter} eksternal.

Para ahli membagi faktor-faktor yang mempengaruhi karakter menjadi dua bagian yaitu internal dan

\subsubsection{Faktor Internal \\ Insting Atau Naluri}

Setiap manusia pasti akan dipengaruhi oleh naluri sebelum beraktivitas. Dampak naluri pada orang alami bergantung pada arahnya. Naluri dapat saja merugikan orang lain, te namun ketika kebenaran mengarah pada halhal yang baik, hal itu dapat sangat meningkatkan karakkter seseorang [13]. Karena naluri berkait erat dengan roh manusia, tidak ada keraguan bahwa makhluk tertinggi yang diciptakan oleh Tuhan adalah orang yang memiliki akal dan perasaan.

\section{Kebiasaan atau Adat}

Kebiasaan merupakan elemen penting dari perilaku manusia. Kebiasaan adalah perilaku yang berulangulang untuk menyederhanakan kebiasaan[14]. Kebiasaan baik dan buruk berpengaruh besar pada perkembangan moral manusia, seperti air dan minyak, dan kebiasaan buruk tidak bisa digabungkan dengan kebiasaan baik.

\section{Kemauan atau Kehendak}

Kemauan adalah salah satu kekuatan di balik tindakan, hal tersebut adalah kekuatan yang secara serius memotivasi orang untuk bertindak (moral) untuk mengekspresikan kebaikan dan kejahatan dan dapat menjadi arah untuk mewujudkan ide apa pun [15]. Kemauan atau kehendak tidak bisa dipisahkan dengan niat. Jika niat ini didasarkan pada perintah Tuhan seperti ibadah, maka akan mendapatkan pahala.

\section{Suara Hati atau Suara Batin}

Manusia di dalam dirinya terkadang memiliki kekuatan untuk memperingatkan, ketika perilaku manusia terancam dan buruk, kekuatan tersebut adalah suara hati atau hati nurani. Selain keinginan untuk berbuat baik, suara hati menyampaikan peringatan dan upaya untuk menghindari bahaya perilaku buruk [16]. Jelas hati nurani atau batin ini bagi orang biasa untuk melakukan sesuatu yang buruk pada hati mereka atau mengatakan bahwa mereka memiliki hati yang rendah, te namun karena setan, orang lebih tertarik pada daya mereka.

\subsubsection{Faktor Eksternal}

Pendidikan

Pendidikan berdampak besar pada pembentukan karakter. Pendidikan membantu perilaku seseorang menjadi dewasa agar sesuai dengan perilaku pendidikan formal atau informal. Unsur pendidikan sangat penting sehingga disposisi individu berkembang dan terkendali dengan baik [17] Pendidikan merupakan investasi bagi masa depan masyarakat, khususnya anak orang tua. Jika anak berpendidikan rendah, hasilnya akan mengecewakan, te namun jika anak berpendidikan baik, orang tua pasti akan senang.

\section{Lingkungan}

Salah satu aspek yang membantu membentuk sikap dan perilaku individu adalah faktor lingkungan tempat mereka hidup. Lingkungan mengacu pada makhluk hidup, bumi, dan langit, dan istilah lingkungan manusia mengelilingi manusia dalam arti yang luas [18]. Lingkungan ini juga berperan penting dalam pembentukan karakter. Anak-anak yang tinggal di pesantren pasti berbeda dengan anak-anak yang tinggal di lingkungan prostitusi dalam hal pengetahuan agama.

\subsection{Dampak Covid-19 terhadap Implementasi Pendidikan Karakter}

Sebagian besar negara di dunia yang lazim saat ini dipengaruhi oleh Covid-19, memaksa hampir semua negara untuk mengikuti aturan dan pedoman pemerintah. Contoh spesifiknya adalah penggunaan masker, artinya, harga masker naik lima kali lipat karena tingginya permintaan [19]. Dengan merebaknya virus Covid-19, perilaku baru seperti mencuci tangan pakai sabun dan menggunakan masker harus menjadi kebiasaan di dalam masyarakat. Staf medis mengenakan masker saat bekerja, namun banyak orang di luar malah tidak berkenan menggunakan masker. Beberapa orang jarang atau enggan mencuci tangan atau menggunakan pembersih tangan. Secara umum, du peristiwa tersebut dianggap ganjil. Namun hari ini keduanya tidak bisa dihindari. Hal Ini membuktikan bahwa orang-orang yang dulunya tidak terbiasa dengan kehidupan bersih dan sehat dan batuk serta bersin kini menjadi masalah di seluruh dunia.

Virus Covid-19 diproduksi oleh tetesan pernapasan yang dipicu oleh satu orang dan lainnya. Jika tangan menyentuh permukaan yang terkontaminasi, virus ditularkan. Kemudahan penularan Covid-19 mengedukasi masyarakat tentang lingkungan. Hal Ini memengaruhi karakter seseorang sebagai respons terhadap wabah Covid19 Seperti yang dijelaskan di atas.

Para ahli membagi faktor-faktor yang mempengaruhi karakter menjadi dua bagian: internal dan eksternal. Dari lima faktor intrinsik yang mempengaruhi karakter, ada empat yang sudah diterapkan oleh penderita quid-19. Naluri atau insting, kebiasaan, keinginan dan kesadaran, faktor pertama adalah naluri atau insting. naluri seseorang menghadapi suatu masalah, terutama dalam hal melindungi jiwanya, menjadi sangat penting. Seseorang akan 
merasa khawatir saat melihat orang lain membawa Covid-19. Ini adalah naluri atau insting, dan faktor kedua adalah kebiasaan. Untuk tetap sehat, terutama jika mencuci tangan dengan sabun dan memakai masker selama wabah Covid-19.

Kebiasaan yang digunakan setiap hari dan tetap sama setelah munculnya Covid-19 adalah kebiasaan menjaga kebersihan dan kebersihan agar tidak sakit, dan faktor ketiga adalah kemauan. ada keinginan untuk kembali ke kehidupan normal seperti semula, tidak peduli seberapa kuat seseorang mungkin sudah memiliki kemauan yang kuat, dia selalu tinggal di rumah. Faktor terakhir adalah kesadaran. Kesadaran adalah inti dari tiga faktor di atas, karena kurang peka terhadap pengaruh kesadaran dan orang lain yang terpengaruh oleh suara hati. Juga, contoh kehati-hatian untuk Covid-19 adalah ketika dua orang memilih opsi (2), antara saat menaiki kereta yang sangat padat hingga saat jumlah penumpang yang sedikit. Mereka memakai masker dan naik taksi dengan sopir yang tidak bermasker.

Jika setiap orang bertindak secara sadar dan sistematis, pembentukan karakter akan berhasil baik dilakukan dengan sadar atau di bawah aturan pemerintah. Tujuan pendidikan karakter yang sukses adalah untuk meningkatkan kesadaran di alam diri secara terus menerus, niscaya implementasi pendidikan karakter dalam menghadapi wabah covid-19 akan berhasil.

\section{KESIMPULAN}

Sebagian besar negara di dunia yang lazim saat ini dipengaruhi oleh Covid-19, memaksa hampir semua negara untuk mengikuti aturan dan pedoman pemerintah. Hal Ini membuktikan bahwa orang-orang yang dulunya tidak terbiasa dengan kehidupan bersih dan sehat dan batuk serta bersin kini menjadi masalah di seluruh dunia. Virus Covid-19 diproduksi oleh tetesan pernapasan yang dipicu oleh satu orang dan lainnya. Jika tangan menyentuh permukaan yang terkontaminasi, virus ditularkan.

Hal Ini memengaruhi karakter seseorang sebagai respons terhadap wabah Covid-19 Seperti yang dijelaskan di atas. Dari lima faktor intrinsik yang mempengaruhi karakter, ada empat yang sudah diterapkan oleh penderita quid-19. Kebiasaan yang digunakan setiap hari dan tetap sama setelah munculnya Covid-19 adalah kebiasaan menjaga kebersihan dan kebersihan agar tidak sakit, dan faktor ketiga adalah kemauan. ada keinginan untuk kembali ke kehidupan normal seperti semula, tidak peduli seberapa kuat seseorang mungkin sudah memiliki kemauan yang kuat, dia selalu tinggal di rumah.

Kesadaran adalah inti dari tiga faktor di atas, karena kurang peka terhadap pengaruh kesadaran dan orang lain yang terpengaruh oleh suara hati. Juga, contoh kehati-hatian untuk Covid-19 adalah ketika dua orang memilih opsi , antara saat menaiki kereta yang sangat padat hingga saat jumlah penumpang yang sedikit. Mereka memakai masker dan naik taksi dengan sopir yang tidak bermasker. Tujuan pendidikan karakter yang sukses adalah untuk meningkatkan kesadaran di alam diri secara terus menerus, niscaya implementasi pendidikan karakter dalam menghadapi wabah covid-19 akan berhasil.

\section{DAFTAR PUSTAKA}

[1] G. Mustikaningrum, L. Pramusinta, S. A. Muhtar Umar Buamona, E. Cahyadi, and W. Istiqomah, "IMPLEMENTASI PENDIDIKAN KARAKTER TERINTEGRASI KURIKULUM DAN METODE PEMBELAJARAN PADA MASA PANDEMI COVID-19," AULADUNA J. Pendidik. Dasar Islam, vol. 7, no. 2, p. 154, Dec. 2020, doi: 10.24252/10.24252/auladuna.v7i2a5.2020.

[2] R. H. Syah, "Dampak Covid-19 pada Pendidikan di Indonesia: Sekolah, Keterampilan, dan Proses Pembelajaran," SALAM J. Sos. dan Budaya Syar-i, vol. 7, no. 5, Apr. 2020, doi: 10.15408/sjsbs.v7i5.15314.

[3] W. A. F. Dewi, "Dampak COVID-19 terhadap Implementasi Pembelajaran Daring di Sekolah Dasar," EDUKATIF J. ILMU Pendidik., vol. 2, no. 1, pp. 55-61, Apr. 2020, doi: 10.31004/edukatif.v2i1.89.

[4] A. M. Saifulloh and M. Darwis, "Manajemen Pembelajaran dalam Meningkatkan Efektivitas Proses Belajar Mengajar di Masa Pandemi Covid-19," Bidayatuna J. Pendidik. Guru Mandrasah Ibtidaiyah, vol. 3, no. 2, p. 285, Oct. 2020, doi: 10.36835/bidayatuna.v3i2.638.

[5] R. Dwi Ariyanto, P. Studi Bimbingan dan Konseling, and U. Nusantara PGRI Kediri, IMPLEMENTASI PENDIDIKAN KARAKTER DI MASA PANDEMI COVID-19: TANTANGAN DAN KONTRIBUSI Santy Andrianie Guruh Sukma Hanggara, vol. 1, no. 1. 2020.

[6] D. Robandi and M. Mudjiran, "Dampak Pembelajaran Dari Masa Pandemi Covid-19 terhadap Motivasi Belajar Siswa SMP di Kota Bukittinggi,” J. Pendidik. Tambusai, vol. 4, no. 3, pp. 3498-3502, Dec. 2020, doi: 10.31004/jptam.v4i3.878.

[7] N. Jannah and K. Umam, "Peran Orang Tua dalam Pendidikan Karakter Berbasis Keluarga di Masa Pandemi Covid-19," FALASIFA J. Stud. Keislam., vol. 12, no. 1, pp. 95-115, Mar. 2021, doi: 10.36835/falasifa.v12i1.460.

[8] M. S. Mubin, "PENDIDIKAN KARAKTER MENURUT IBNU MISKAWAIH DAN 
IMPLEMENTASINYA TERHADAP PEMBELAJARAN MASA PANDEMI,” J. REFORMA, vol. 9, no. 2, p. 114, Dec. 2020, doi: 10.30736/rf.v9i2.319.

[9] I. P. Yoga Purandina and I. M. Astra Winaya, "Pendidikan Karakter di Lingkungan Keluarga Selama Pembelajaran Jarak Jauh pada Masa Pandemi COVID-19,” Cetta J. Ilmu Pendidik., vol. 3, no. 2, pp. 270290, Jun. 2020, doi: 10.37329/cetta.v3i2.454.

[10] Y. Karneli, "UPAYA GURU BK/KONSELOR UNTUK MENURUNKAN PERILAKU AGRESIF SISWA DENGAN MENGGUNAKAN KONSELING KREATIF DALAM BINGKAI MODIFIKASI KOGNITIF PERILAKU," Pedagog. J. Ilmu Pendidik., vol. 18, no. 2, p. 32, Apr. 2019, doi: 10.24036/fip.100.v18i2.430.000-000.

[11] L. N. Atiqoh, "RESPON ORANG TUA TERHADAP PEMBELAJARAN DARING PADA MASA PANDEMI COVID-19," Thufuli J. Ilm. Pendidik. Islam Anak Usia Dini, vol. 2, no. 1, p. 45, Jul. 2020, doi: 10.33474/thufuli.v2i1.6925.

[12] A. Abdusshomad, "Pengaruh Covid-19 terhadap Penerapan Pendidikan Karakter dan Pendidikan Islam," QALAMUNA J. Pendidikan, Sos. dan Agama, vol. 12, no. 2, 2020, doi: 10.37680/qalamuna.v12i2.407.

[13] I. Wayan, E. Santika, P. Studi, P. Pancasila, and D. Kewarganegaraan, "Pendidikan Karakter pada Pembelajaran Daring," IVCEJ, vol. 3, no. 1, pp. 8-19, Aug. 2020, Accessed: May 26, 2021. [Online]. Available: https://ejournal.undiksha.ac.id/index.php/IVCEJ/article/view/27830.

[14] P. Panoyo, Y. Riyanto, and W. Handayaningrum, "Manajemen Penguatan Pendidikan Karakter Pada Sekolah Menengah Atas," Halaqa Islam. Educ. J., vol. 3, no. 2, p. 111, Jan. 2020, doi: 10.21070/halaqa.v3i2.2714.

[15] C. F. Pasani, E. Kusumawati, and D. Imanisa, "PENERAPAN MODEL PEMBELAJARAN KOOPERATIF TIPE SCRAMBLE DALAM PEMBELAJARAN MATEMATIKA UNTUK MEMBINA KARAKTER TANGGUNG JAWAB DAN DISIPLIN SISWA,” EDU-MAT J. Pendidik. Mat., vol. 6, no. 2, Dec. 2018, doi: 10.20527/edumat.v6i2.5682.

[16] F. T. Nafisah and A. A. Zafi, "Model Pendidikan Karakter Berbasis Keluarga Perspektif Islam di Tengah Pendemi Covid-19," Ta'allum J. Pendidik. Islam, vol. 8, no. 1, Jun. 2020, doi: 10.21274/taalum.2020.8.1.1-20.

[17] J. Rihlah, U. Kamilah, and D. Shari, "Gambaran Pendidikan Karakter Anak Usia Dini di Masa Pandemi covid-19,” PAUD Lect. J. Pendidik. Anak Usia Dini, vol. 4, no. 01, pp. 51-61, Sep. 2020, doi: 10.31849/paud-lectura.v4i01.4878.

[18] M. Z. Ahmadi, H. Haris, and M. Akbal, "Implementasi Program Penguatan Pendidikan Karakter Di Sekolah,” Phinisi Integr. Rev., vol. 3, no. 2, p. 305, Sep. 2020, doi: 10.26858/pir.v3i2.14971.

[19] S. Islam, "KARAKTERISTIK PENDIDIKAN KARAKTER; MENJAWAB TANTANGAN MULTIDIMENSIONAL MELALUI IMPLEMENTASI KURIKULUM 2013," EDURELIGIA; J. Pendidik. AGAMA Islam, vol. 1, no. 2, pp. 89-100, Feb. 2017, doi: 10.33650/edureligia.v1i2.50. 